\title{
Digital servitization strategies for SME internationalization: the interplay between digital service maturity and ecosystem involvement
}

\author{
Milad Kolagar and Wiebke Reim \\ Entrepreneurship and Innovation, Lulea University of Technology, \\ Luleå, Sweden \\ Vinit Parida \\ Entrepreneurship and Innovation, Lulea University of Technology, \\ Luleå, Sweden and \\ Department of Management, University of Vaasa, Vaasa, Finland, and \\ David Sjödin \\ Entrepreneurship and Innovation, Luleà University of Technology, \\ Luleå, Sweden
}

\begin{abstract}
Purpose - The purpose of this study is to understand how digital servitization enables the process of internationalization for industrial SMEs.

Design/methodology/approach - The present study has adopted an exploratory multiple case study, conducting a total of 40 interviews in a two-phased approach to data collection. The first phase consisted of exploratory interviews with twenty-six industrial SMEs connected to the manufacturing industry in Sweden and Finland. Then, six SMEs were selected in the second phase to participate in additional in-depth interviews.

Findings - First, this study identifies three gradual enabling phases concerned with the digital service maturity of SMEs consisting of digital awareness, digital service innovation and digital service mass customization. Second, the three interdependent phases of ecosystem knowledge synergy, ecosystem integration and ecosystem value co-creation were identified to improve ecosystem involvement. Finally, a process framework has been developed for SME internationalization consisting of a digital servitization innovation strategy, a digital servitization ecosystem strategy and a digital servitization scaling strategy.

Originality/value - The present research contributes to how digital servitization enables SME internationalization by demonstrating how the development of digital service offerings and ecosystem partnerships supports the internationalization process. This research extends the literature by proposing a process framework for the digital-servitization-enabled internationalization of SMEs. This process perspective
\end{abstract}

(C) Milad Kolagar, Wiebke Reim, Vinit Parida and David Sjödin. Published by Emerald Publishing Limited. This article is published under the Creative Commons Attribution (CC BY 4.0) licence. Anyone may reproduce, distribute, translate and create derivative works of this article (for both commercial and non-commercial purposes), subject to full attribution to the original publication and authors. The full terms of this licence may be seen at http://creativecommons.org/licences/by/4.0/legalcode

This paper forms part of a special section "The Future of Servitization in a Digital Era (Part 2)", guest edited by Christian Kowalkowski, Tim Baines and Ali Ziaee Bigdeli.

Funding: The authors gratefully acknowledge the contributors of funders which made this research possible: Vinnova, PiiA, Intereg Nord and Intereg Bothnia Atlantica.

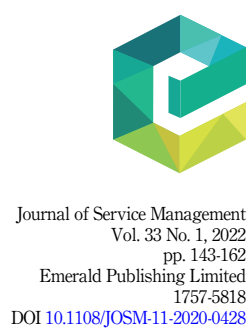


JOSM

33,1 provides a richer explanation of the complex interplay between servitization, digitalization and ecosystems choices, which supports the expansion into international markets.

Keywords Internationalization, SMEs, Digital servitization, Digital service maturity, Business ecosystem, Ecosystem involvement

Paper type Research paper

\section{4}

\section{Introduction}

Digital servitization, an increasingly prevalent trend in industry, is defined as "the transformation in processes, capabilities, and offerings within industrial firms and their associate ecosystems to progressively create, deliver, and capture increased service value arising from a broad range of enabling digital technologies such as the internet of Things (IoT), big data, artificial intelligence (AI), and cloud computing" (Sjödin et al., 2020b, p. 478). While most commonly discussed in the context of large manufacturing firms (Martín-Peña et al., 2020; Naik et al., 2020), digital servitization can also generate significant growth opportunities for small and medium-sized enterprises (SMEs) by creating increased value for customers, scaling their technological capabilities, and expanding their reach into global markets (Reim et al., 2019). In particular, digital servitization provides an opportunity for industrial SMEs to transcend their liability of "localness" and expand their international presence through online support features and advanced digital services (Schroeder et al., 2020; Ziaee Bigdeli et al., 2018). For example, remote monitoring and preventive maintenance services offer SMEs opportunities to support customers globally and generate new service revenue streams (Sklyar et al., 2019; Tronvoll et al., 2020). Indeed, this global scalability of digital services may be a competitive necessity for industrial SMEs to recoup their investment in digitalization by attracting a sufficient number of customers.

However, succeeding with digital servitization and offering digital services on a global scale is not without challenges for industrial SMEs. For example, SMEs usually face digital servitization barriers, such as a product-centric strategy, a lack of digital skills and resources, challenges to networking with other companies, and the traditional mindset of leaders and entrepreneurs (Peillon and Dubruc, 2019; Roy et al., 2016). One of the ways that SMEs can overcome these barriers is to develop their digital servitization capabilities. However, increased development of digital services is not enough. To reach and support customers globally, industrial SMEs commonly need ecosystem partnerships to facilitate the sale and delivery of digital service offerings internationally. More specifically, in their local markets, SMEs are well integrated with their delivery partners and operate in a stable ecosystem. Yet, for international markets, new and even non-traditional partnerships could usefully be fostered. The challenge for SMEs is to build new ecosystems and to align with an array of partners in order to deliver a digital value proposition (Adner, 2017).

The literature on digital servitization is in an emergent phase (Gebauer et al., 2021; Kohtamäki et al, 2020), and the SME perspective has received little coverage thus far (Peillon and Dubruc, 2019). We have identified three research gaps in the digital servitization and internationalization literature on industrial SMEs. First, there is a need to develop a better understanding of how digital servitization in industrial SMEs can lead to more advanced levels of digital service offerings suitable for the pursuit of international growth. This transformation is occurring gradually, and companies are gaining experience, depending on their effectiveness in redesigning their processes, products and services using digital technology. Researchers agree that increased understanding of how to design more advanced digital service offerings is a prerequisite for identifying appropriate steps to increase international business (Kohtamäki et al., 2019; Sklyar et al., 2019). Second, further insights into how industrial SMEs can involve ecosystem partners in growing their international sales of digital services are needed. Prior research recognizes that SMEs usually have limited 
competencies and legitimacy to build relationships with ecosystem partners such as delivery actors (Cormican, 2010; Senik et al., 2011; Su et al., 2020). Thus, it is important to seek understanding of the underlying activities that industrial SMEs require to secure alignment in different phases of ecosystem partnerships. Finally, understanding the evolution of digital service offerings and capabilities for ecosystem partnerships are central but not enough in isolation. Industrial SMEs are much more heterogenous groups and adopt diverse strategies for internationalization. Thus, there is a need to conceptualize the internationalization paths that SMEs engaged in digital servitization follow (Donaldson, 2001; Thompson, 2003).

Against this background, the purpose of this study is to understand how digital servitization enables the process of internationalization for industrial SMEs. To achieve our purpose, we build on a multiple case study of twenty-six industrial SMEs engaged in digital servitization and internationalization. This study contributes to the digital servitization literature in two ways. First, we investigate the important issue of how industrial SMEs internationalization can be supported by digital servitization. In particular, the study sheds light on how efforts to increase digital service maturity co-evolves with ecosystem involvement. The joint development of these two underlying activities promises an expansion of SME growth and competitiveness. Second, we contribute to the literature by providing a process framework for the digital-servitization-enabled internationalization of industrial SMEs. This perspective provides a richer explanation of the complex interplay between servitization, digitalization and ecosystem choices that SMEs could usefully consider if they wish to expand their businesses into global markets.

\section{Theoretical background}

In order to better understand the background of this research, this section sheds light on the main concepts being used by our research and explains how they relate to each other. After defining, describing and synthesizing these concepts in the literature, we explain and interpret the main gaps in the literature regarding digital servitization for SME internationalization.

\subsection{Conceptual background}

Digitalization has led many industrial firms to search for ways to move from product-centric models to providing digital service-oriented offerings (Kohtamäki et al., 2020; Kowalkowski et al., 2017). Companies, and especially industrial SMEs, have realized the potential to satisfy customer needs by providing services and solutions instead of selling only products. This trend has been described as servitization (Raddats et al., 2019; Reim et al., 2019; Ziaee Bigdeli et al., 2017). Servitization helps companies to differentiate themselves, although the use of new digital technologies (e.g. AI, sensors, connectivity) is usually required for success (Martín-Peña et al., 2020). Using these digital technologies, organizations seek to create value in their businesses and offer an enhanced customer experience. From this has emerged a new concept in the servitization literature called "digital servitization" (Coreynen et al., 2020; Gebauer et al., 2021; Paschou et al., 2020) where companies adapt to current technological developments by offering digitally enabled advanced services (Schroeder et al., 2020; Ziaee Bigdeli et al., 2018). In a nutshell, the progression of offerings in digital servitization can be defined as the transition toward smart product-service-software systems that enable value creation and capture through monitoring, control, optimization, and autonomous function (Kohtamäki et al., 2019). This transition requires a series of transformations in firms and their associate ecosystem processes, capabilities and offerings to create, deliver and capture increased service value (Sjödin et al., 2020b). Their new service offerings are made possible by deploying a broad range of digital technologies (Sjödin et al., 2020b; Sklyar et al., 2019). As most firms, especially industrial SMEs, are facing limitations 
JOSM

33,1

146

in their capabilities, expertise and resources (Kowalkowski et al., 2013), an ecosystem perspective is advantageous for digital servitization (Kohtamäki et al., 2019; Sklyar et al., 2019). In other words, no firm can claim to have access to all the resources, capabilities and expertise required to provide their digitally enabled advanced services (Kamalaldin et al., 2021). As a result, they need to look for suitable partners to fill their technological gaps to make up for these shortcomings in the digital servitization process. Accordingly, an ecosystem refers to "the alignment structure of the multilateral set of partners that need to interact in order for a focal value proposition to materialize" (Adner, 2017, p. 40). Indeed, creating a collaborative environment that ensures precise and multifaceted collaborations between actors within an organization, as well as external actors, is critical to the successful implementation of digital servitization (Sklyar et al., 2019). The reason behind this is that intelligent services and smart solutions typically have to be designed to work with those from other manufacturers. Besides manufacturers, these services and solutions must be compatible with those of the customers, distributors and the rest of the ecosystem actors who participate in digital servitization (Kohtamäki et al., 2019).

Digital servitization is increasingly seen as the growth engine of industrial companies accelerating their sales growth in international markets - referred to as internationalization (Denicolai et al., 2021; Sinkovics et al., 2013). Internationalization is a complex process and can be approached from various theoretical perspectives (Kraus et al., 2016). In connection with the internationalization of small and medium-sized enterprises, various models have been proposed in the literature. The Uppsala internationalization model (U-model) and the Innovation-related models (I-models) can be considered the most important ones (Matlay et al., 2006; Vahlne, 2020). In accordance with the ecosystem perspective, network theory can shed light on how different actors, resources, and processes (Håkansson and Snehota, 2017) within an ecosystem setting can impact the internationalization of SMEs. Moreover, internationalization is one of the most important ways of achieving business growth (Ayden et al., 2021; Niittymies and Pajunen, 2020) and may be the critical factor in achieving the required scale - where sufficient sales in digital offerings are generated (Reim et al., 2021; Sjödin et al., 2020b). Due to the general resource constraints on them, SMEs could profitably learn how to acquire the ability to utilize versatile and cost-effective digital resources, such as remote monitoring technologies and infrastructures, to expand their international footprint (Pergelova et al., 2019). Although internationalization is increasingly important for industrial firms engaged in digital servitization, considerable ambiguity still exists on how to approach digital servitization and how best to utilize it as an enabler of international market expansion, especially in industrial SMEs.

\subsection{Digital servitization for SME internationalization}

Based on what we have learned collectively from prior research, the SME-context dialogue is fragmented within the servitization, digital servitization, ecosystem and internationalization literature streams. We have, therefore, identified the main streams where the focus is on servitization [S], digital servitization [DS], ecosystems [E] and internationalization [I]. We then reviewed the SME literature on these streams to identify the main sources and core references that established links between these streams (see Table 1). The table indicates which literature stream each article is focused on, the method used, and the key findings and research gaps identified. Compared to other papers, this paper focuses on all these streams and how they relate to each other to fulfill our research purpose and to contribute to the literature. Our review of the literature has revealed three critical gaps. First, digital servitization is a challenge that SMEs may interpret in ways that are not always helpful. These misinterpretations can lead to confusion on how best to scale the business in the international market. SMEs often assume that using new technologies and making their processes more efficient is sufficient to put them on the right track for digital transformation (Coreynen et al., 2017; Peillon and Dubruc, 2019). But often they become engaged in the dream of digitalization and find difficulty in moving 


\begin{tabular}{|c|c|c|c|c|c|}
\hline $\begin{array}{l}\text { Author(s) and } \\
\text { year }\end{array}$ & Stream & Methodology & Key findings & Research gaps (to address) & servitization \\
\hline $\begin{array}{l}\text { Adrodegari and } \\
\text { Saccani (2020) }\end{array}$ & $\mathrm{S}$ & $\begin{array}{l}\text { Literature-based } \\
\text { approach, } 2 \text { SMEs }\end{array}$ & $\begin{array}{l}\text { Developing a servitization maturity } \\
\text { model for assessing and positioning } \\
\text { companies in the servitization } \\
\text { journey }\end{array}$ & $\begin{array}{l}\text { Empirical evidence mainly } \\
\text { concerns large multinational } \\
\text { companies, while SMEs' attempts } \\
\text { to servitize are not much } \\
\text { investigated }\end{array}$ & rrateo \\
\hline \multirow{2}{*}{$\begin{array}{l}\text { Queiroz et al. } \\
\text { (2020) }\end{array}$} & \multirow[t]{2}{*}{$\mathrm{S}$} & \multirow{2}{*}{$\begin{array}{l}\text { PLS-SEM } \\
\text { modeling, } 176 \\
\text { SMEs }\end{array}$} & \multirow{2}{*}{$\begin{array}{l}\text { A positive relationship between } \\
\text { servitization and SME performance }\end{array}$} & \multirow{2}{*}{$\begin{array}{l}\text { Scarcity of empirical evidence } \\
\text { demonstrating the impact of } \\
\text { servitization on SME performance }\end{array}$} & 14 \\
\hline & & & & & \\
\hline $\begin{array}{l}\text { Weerawardena } \\
\text { et al. }(2020)\end{array}$ & I & $\begin{array}{l}\text { PLS-SEM } \\
\text { modeling, } 157 \\
\text { SMEs }\end{array}$ & $\begin{array}{l}\text { The results showed that market } \\
\text { learning drives other learning } \\
\text { capabilities in the firm to contribute } \\
\text { collectively to innovation and, in } \\
\text { turn, international market } \\
\text { outcomes }\end{array}$ & $\begin{array}{l}\text { The challenges presented by the } \\
\text { unique characteristics of services } \\
\text { particularly in marketing } \\
\text { internationally must be recognized. } \\
\text { Also, the knowledge resources and } \\
\text { capabilities that drive service } \\
\text { innovation-based competitive } \\
\text { advantages remain under- } \\
\text { researched. In addition, it is } \\
\text { questioned in the service } \\
\text { innovation literature whether } \\
\text { service innovation-based } \\
\text { competitive advantages can be } \\
\text { sustained }\end{array}$ & \\
\hline $\begin{array}{l}\text { Benitez et al. } \\
(2020)\end{array}$ & $\mathrm{E}$ & $\begin{array}{l}\text { Survey and } \\
\text { interviews, } 87 \\
\text { SMEs }\end{array}$ & $\begin{array}{l}\text { The final framework shows that the } \\
\text { ecosystem's mission shifted from } \\
\text { accessing innovation funds to } \\
\text { Industry } 4.0 \text { solution co-creation } \\
\text { and, then, to smart business } \\
\text { solutions co-creation }\end{array}$ & $\begin{array}{l}\text { Little is known about how to } \\
\text { systematize the efforts of SMEs } \\
\text { through the promotion of } \\
\text { innovation ecosystems for the } \\
\text { co-creation of Industry } 4.0 \\
\text { solutions. Prior research has } \\
\text { predominantly focused on Industry } \\
4.0 \text { technology adopters, i.e. the } \\
\text { demand side, while there is still a } \\
\text { gap in the literature referring to the } \\
\text { study of technology providers, i.e. } \\
\text { the offering side }\end{array}$ & \\
\hline Kahle et al. (2020) & $\mathrm{E}$ & $\begin{array}{l}\text { Case study } \\
\text { method, } 120 \text { SMEs }\end{array}$ & $\begin{array}{l}\text { Developing a conceptual } \\
\text { framework that presents the } \\
\text { required characteristics of an } \\
\text { innovation ecosystem to offer } \\
\text { smart products, and discloses the } \\
\text { relationships among these } \\
\text { characteristics }\end{array}$ & $\begin{array}{l}\text { The development of smart products } \\
\text { requires knowledge and capabilities } \\
\text { that single companies usually do not } \\
\text { possess, thus creating new } \\
\text { opportunities for cooperation } \\
\text { through the establishment of } \\
\text { innovation ecosystems focused on } \\
\text { smart products }\end{array}$ & \\
\hline $\begin{array}{l}\text { Peillon and } \\
\text { Dubruc (2019) }\end{array}$ & DS & $\begin{array}{l}\text { Literature analysis } \\
\text { and multiple case } \\
\text { study, 8 SMEs }\end{array}$ & $\begin{array}{l}\text { Identifying the main barriers that } \\
\text { French manufacturing SMEs face } \\
\text { in their move toward digital } \\
\text { servitization }\end{array}$ & $\begin{array}{l}\text { Even though digitalization can } \\
\text { offer vast opportunities for SMEs to } \\
\text { enter new markets, the digital } \\
\text { transformation path is not obvious, } \\
\text { and manufacturing SMEs face } \\
\text { major barriers and obstacles to } \\
\text { digital servitization }\end{array}$ & $\begin{array}{r}\text { Table } 1 . \\
\text { Overview of some key } \\
\text { references within the }\end{array}$ \\
\hline & & & & (continued) & $\begin{array}{r}\text { SME context regarding } \\
\text { each stream }\end{array}$ \\
\hline
\end{tabular}


JOSM 33,1
Author(s) and
year

\begin{tabular}{lll} 
year & Stream & Methodology \\
\hline Genc et al. (2019) & I & $\begin{array}{l}\text { PLS-SEM } \\
\text { modeling, 235 } \\
\text { SMEs }\end{array}$
\end{tabular}

\section{8}

The results indicated that the
degree of internationalization
positively affects innovation
performance and, more
importantly, that this relationship
is indirect and fully mediated by the
market and entrepreneurial
orientation of SMEs

$\begin{array}{lll}\text { Radziwon and } & \text { E } & \begin{array}{l}\text { Multiple case } \\ \text { study, 7 SMEs }\end{array}\end{array}$

Valtakoski and Witell (2018)

Coreynen et al. (2017)

Galkina and Chetty (2015)

Kowalkowski et al. (2013)
$\mathrm{S}$

(n)

Survey study, 224
SMEs

The results established a particular set of challenges for the SMEs due to the misalignment between their business models and their ecosystems

Studying the impact of back-office (BO) service capability and frontoffice (FO) service capability, and how firm age influences the impact of these service capabilities on SME performance

\section{S, DS Multiple case} study, 4 SMEs

Understanding how digitalization can enable manufacturing companies to offer a higher level of value-added services to their customers

The results showed how entrepreneurs network with interested partners instead of carefully selecting international partners according to predefined network goals

\section{S, E Multiple case} study, 13 SMEs
Investigating how SMEs construct new value constellations that enable value creation through services
Research gaps (to address)

Little effort has been made to test and examine how internationalization fosters or hinders a firm's innovation performance. In fact, there is no consensus about the underlying mechanism of this relationship and direct and/or indirect effects of seeking internationalization on innovation

Few studies have focused on open innovation in business ecosystems, thus amplifying the lack of understanding of how SMEs can manage open innovation in such ecosystems

Underexplored areas in addressing the impact of capabilities on firm performance

Lack of clearance between servitization-related capabilities and their relative importance Not enough is known about how manufacturers can effectively leverage digital means to increase their service offering

The internationalization process often lacks strategic orientation. This relates to the fact that decision making is done under conditions of uncertainty and goal ambiguity, and the relationship component makes this process difficult to predict

No explicit investigations consider how SMEs manage to infuse service into their business

Table 1.

Note(s): S = Servitization, DS = Digital Servitization, E = Ecosystem, I = Internationalization

beyond the early stages of visualizing and designing to implementing and scaling. We share a particular interest in how SMEs can best develop the degree of maturity that leveraging digital technology requires so that their digital service offerings can achieve the greater level of sophistication demanded. Second, implementing digital servitization requires widened cooperation with ecosystem partners (Sklyar et al., 2019). The rapid advancements in digital technologies make it very difficult for one single firm to keep up with the speed of change (Tronvoll et al., 2020; Linde et al., 2021). Therefore, having an ecosystem perspective is useful, as ecosystem actors complement each other's capabilities, resources, technologies and offerings, to develop and deliver digitally enabled advanced services to their customers (Kamalaldin et al., 2021). Accordingly, for successful sales growth globally, industrial SMEs need to consider how best to approach alignment with partners and secure their role in a competitive ecosystem (Adner, 2017). Finally, since SMEs are heterogeneous in terms of size, capabilities, digital maturity, partners, and international market presence, they may follow different strategies to internationalization. Given the lack of coverage in the literature, there is a sound argument for a 
more process-based perspective, particularly from an SME standpoint. Obviously, there will be no one-size-fits-all solution to this issue, but our area of study would likely benefit from having a better understanding of how industrial SMEs can use the potential of digital servitization and ecosystem partnerships to go international. Consequently, this research seeks to fill the gaps in the literature by providing a process framework for SME internationalization.

\section{Methodology}

The present study is based on an inductive approach and an exploratory multiple case study involving 26 SMEs from the manufacturing industry or the value chain of manufacturing companies. We studied these companies to investigate different strategies to internationalization for SMEs through digital servitization. This research design was chosen because there is only limited knowledge on how digital servitization and ecosystem partnerships affect the successful internationalization of SMEs. Information from rich real-life cases can help identify new phenomena derived from reality (Eisenhardt and Graebner, 2007a; Yin, 2014). Our approach helps to better understand complex social processes and phenomena such as digital servitization.

The data collection was performed in two phases. The first phase consisted of exploratory interviews with twenty-six companies connected to the manufacturing industry in Sweden and Finland. Building on theoretical sampling (Eisenhardt, 1989; Eisenhardt and Graebner, 2007b), the case selection criteria were informed by the study's purpose - to understand how digital servitization enables the process of internationalization for industrial SMEs. The purpose highlights three aspects: the perspective of belonging to a manufacturing-related industry, the context of SMEs, and a focus on actively pursuing an internationalization strategy based on digital servitization. For the second phase, six of the companies interviewed in the first phase were chosen to participate in additional interviews. These companies had already embarked on an impressive internationalization journey and planned to further increase their international sales. These cases were particularly interesting because of their unique engagement in digital servitization and ecosystems. Two or more follow-up interviews were conducted and a total of 40 interviews were conducted during this twophased approach. An overview of the companies that were interviewed in phase two can be found in Table 2. All interviews were conducted either face to face or by phone using a semistructured questionnaire. The interview questions were structured to explore the company's experience with digital servitization, their internationalization strategy, and how they manage their relations with partners and customers in the ecosystem. Each area of the interview started with an open question on their experience, and these questions were followed up with more specific questions related to the research focus of this study. Each interview lasted approximately 60-90 min and was recorded. The interviewers took notes during the interviews. All the recorded interviews were transcribed for the data analysis. In addition, the transcriptions were supplemented by secondary sources of data, such as internal documents, presentations, company websites and news articles, so that we could use multiple sources of evidence to improve the validity of the research design (Yin, 2017).

We analyzed the data thematically by first organizing and coding the interview data based on the terms, labels and phrases. This was done across multiple respondents to detect conceptual patterns (Glaser and Strauss, 1967) that were similar in their essence. To ensure rigor and increase confidence in the analysis, multiple members of the research group developed the coding scheme independently of each other. In the event of disagreement, we discussed and modified the coding scheme until consensus was reached. This provided an independent perspective on the trustworthiness of the coding schemes (Lincoln and Guba, 1985). The codes were combined into seventeen first-order categories that represent the main activities required to enhance the digital servitization 
JOSM

33,1

\begin{tabular}{|c|c|c|c|c|c|}
\hline $\begin{array}{l}\text { Company } \\
\text { (No. of } \\
\text { employees) }\end{array}$ & Industry & Digital service offering & Turnover & $\begin{array}{l}\text { International } \\
\text { presence (No. of } \\
\text { countries) }\end{array}$ & $\begin{array}{l}\text { Respondents } \\
\text { (No. of } \\
\text { interviews) }\end{array}$ \\
\hline $\begin{array}{l}\text { Company A } \\
\text { (6) }\end{array}$ & Mining & $\begin{array}{l}\text { Process optimization } \\
\text { solution (Providing } \\
\text { optimized process control, } \\
\text { modeling, and simulation } \\
\text { solutions for improving } \\
\text { the quality of outcomes, } \\
\text { increasing the } \\
\text { productivity, and reducing } \\
\text { the environmental } \\
\text { footprints) }\end{array}$ & 10 MSEK & 2 & $\begin{array}{l}\text { CEO (2), Head of } \\
\text { sales (1) }\end{array}$ \\
\hline $\begin{array}{l}\text { Company B } \\
(22)\end{array}$ & Forestry & $\begin{array}{l}\text { Monitoring and control } \\
\text { solutions (Providing } \\
\text { advanced hardware and } \\
\text { software solutions for } \\
\text { remote monitoring and } \\
\text { controlling the functional } \\
\text { safety and reliability of } \\
\text { manufacturing) }\end{array}$ & $28 \mathrm{MSEK}$ & 6 & $\begin{array}{l}\text { CEO (2), Service } \\
\text { engineer (1) }\end{array}$ \\
\hline $\begin{array}{l}\text { Company C } \\
(150)\end{array}$ & Mining & $\begin{array}{l}\text { Site optimization solution } \\
\text { (Providing software } \\
\text { solutions and digital } \\
\text { interfaces for connectivity } \\
\text { and optimization of people, } \\
\text { machines, and equipment } \\
\text { on different sites) }\end{array}$ & $\begin{array}{l}120 \\
\text { MSEK }\end{array}$ & 14 & $\begin{array}{l}\text { CTO (2), } \\
\text { Business } \\
\text { development } \\
\text { manager (2) }\end{array}$ \\
\hline $\begin{array}{l}\text { Company D } \\
\text { (5) }\end{array}$ & $\begin{array}{l}\text { Steel and } \\
\text { metal }\end{array}$ & $\begin{array}{l}\text { Advanced measurement } \\
\text { solution (Providing } \\
\text { intelligent measurement } \\
\text { systems in } 2 \mathrm{D} \text { and } 3 \mathrm{D} \\
\text { technologies for } \\
\text { optimizing the production } \\
\text { process) }\end{array}$ & $\begin{array}{l}4.5 \\
\text { MSEK }\end{array}$ & 4 & $\begin{array}{l}\text { CEO (1), Sales } \\
\text { and marketing } \\
\text { manager (2) }\end{array}$ \\
\hline $\begin{array}{l}\text { Company E } \\
\text { (50) }\end{array}$ & Mining & $\begin{array}{l}\text { Advanced positioning } \\
\text { solution (Providing mobile } \\
\text { location-based services } \\
\text { and solutions with real- } \\
\text { time location, tracking, and } \\
\text { monitoring of people and } \\
\text { machineries in a global } \\
\text { scale) }\end{array}$ & 80 MSEK & 9 & $\begin{array}{l}\text { CEO (2), Area } \\
\text { manager (2) }\end{array}$ \\
\hline $\begin{array}{l}\text { Company F } \\
\text { (10) }\end{array}$ & Forestry & $\begin{array}{l}\text { Autonomous wood drying } \\
\text { process solution } \\
\text { (Providing control system } \\
\text { hardware and software } \\
\text { equipment for drying and } \\
\text { energy optimization with } \\
\text { less power consumption } \\
\text { and less loading time) }\end{array}$ & 12 MSEK & 3 & CEO (3) \\
\hline
\end{tabular}

Table 2.

Company details for the second phase of data collection

transformation and ecosystem partnerships of SMEs. By identifying the relationships between these categories, six second-order themes were then ascertained, which consist of the core capabilities that need to be acquired over three gradual enabling phases. Finally, 
those themes were generalized into two aggregate themes (digital service maturity and ecosystem involvement) at a higher level of abstraction (Braun and Clarke, 2006; Gioia et al., 2013). To validate the coding structure, an inter-judge reliability test was performed. Based on all stages of data analysis, coding structures were compiled as displayed in Figure 1.

\section{Empirical findings}

This study provides insights into how small and medium-sized enterprises can improve (strengthen) their internationalization by investing in digital service maturity and ecosystem involvement. Following the order of aggregate themes in the coding structure (see Figure 1), the relevant findings of this research are described below.

\subsection{Digital service maturity}

Many SMEs aim to develop their digital service offerings, providing customers with solutions rather than selling only products. Digital servitization requires new capabilities to be developed, particularly for SMEs. This is a gradual process involving several stages. Our findings identify three stages of digital service maturity: digital awareness, digital service innovation and digital service mass customization.

4.1.1 Digital awareness. "Digital awareness" can be considered the initial phase, exercising the decisive role in providing digital service offerings. The research data analysis made clear that companies often started their journey by assessing their internal digital readiness. Even though a company's business is based on advanced technology, it does not mean that it has reached a state of high digital readiness when it comes to implementing new digital tools. Companies need them invest in digital technologies to enable digital servitization and to provide new customer offerings. Here, many companies look to use sensors and connectivity devices to collect data on their production and service processes. These technologies facilitate the collection of large amounts of information and create more organized systems. On the issue of investment in digital technologies, the business development manager of Company $\mathrm{C}$ commented:

We need to make heavier investments in our technologies; we need to train our systems to be smarter, and smarter and taking better decisions. Digitalization is everything! We have to deal with huge amounts of data, for instance, more than we've ever had to deal with before when we are

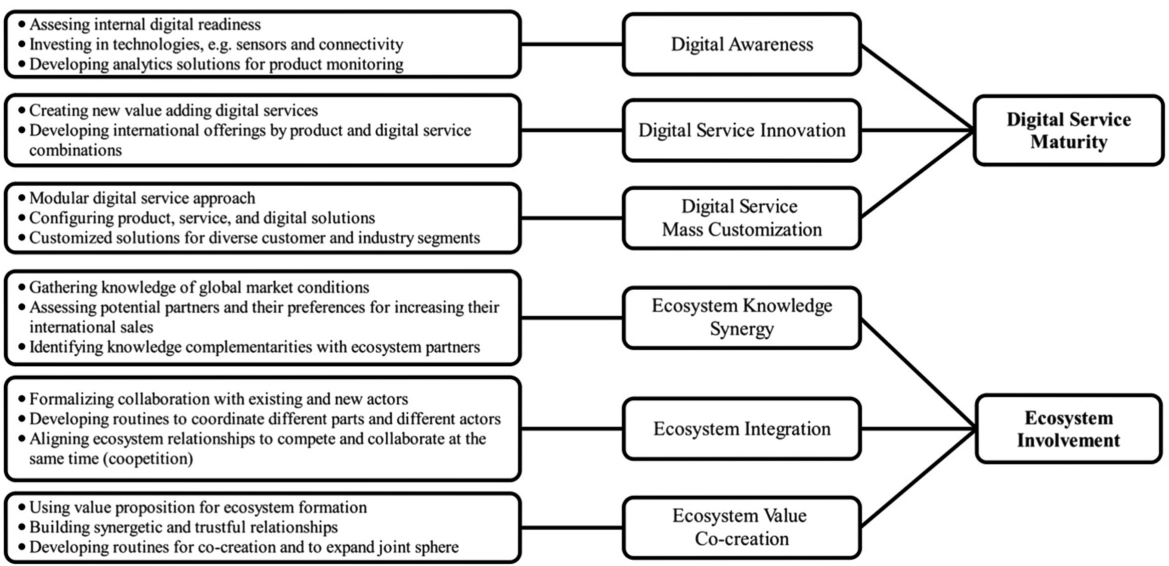

Figure 1.

Data structure and coding process 
JOSM 33,1 gathering lots, and lots, and lots of data. So, for this we need smarter investments, we need to invest in these cutting-edge technologies. That's the challenge as well, and an opportunity.

Eventually, this can lead companies to develop analytics solutions for product monitoring. Indeed, to meet customer needs at both home and abroad, SMEs benefit from being able to develop analytics solutions. In this way, they can gather complete information about the operating conditions of their machines and tools globally and, in the long run, use machine learning and artificial intelligence to analyze information and receive suggestions.

4.1.2 Digital service innovation. After gaining digital awareness, SMEs enter the "digital service innovation" phase where service systems are reconfigured in order to enhance value for customers. Digital service innovation is the use of new digital solutions to meet the needs of new and existing customers and target markets. From the analysis of gathered data, it was clear that companies need to be able to create new value-adding digital services. Indeed, companies can create greater value for customers by developing improved services and devising innovative methods of delivery. The CEO of Company A explained the challenges in creating value-added innovations:

When you're doing an innovation, the hard thing is, of course, to keep going until the market accepts it. If you invent something or, for example, generate a new digital service, it could take a lot of time before ... You always think that everyone likes this, this will be the new Apple or something like that, but it's usually not like this. It really matters what value you are adding by the innovation you made.

Although new technologies are often the main cause of change, their impact is never confined to the industry alone. The key to achieving such a transformation is having a solid and coherent development plan that links new technology to a new need. By developing international offerings in product and digital service combinations, SMEs can integrate their products into customer operations and create value in more business segments as they move toward growth in their international sales.

4.1.3 Digital service mass customization. In the "digital service mass customization" phase, SMEs learn to differentiate between different customers with distinct visions and maturity levels from various industry segments to create diverse types of digital servitization offering based on customer needs.

Analysis of data in this study indicated that SMEs may be best placed to take a modular digital service approach. This concept promotes the idea that firms need to adopt a modular approach to design digital services by putting together different building blocks, which then allows them to scale them up much easier, making it a more manageable proposition to achieve mass customization. This has the advantage that different standard and predefined modules can be combined easily like Lego pieces so that diverse options for service solutions are created to fit specific customer needs. To this end, SMEs put effort into configuring their product, service and digital modules to meet different customer requirements internationally. For example, SMEs could design solutions in the form of outcome-based contracts. In this way, they can use digital modules to devise a type of contract where they ensure that the solution is up and running. To offer this type of customized solution, SMEs need to be quite advanced in their approach. The last step concerns using the configured solutions to offer customized solutions for diverse customer and industry segments. For example, Company B first started to offer digital services to the pulp and paper industry but, having matured along the journey, it learned how to take its digital offering into other industry sectors and expand it globally. The CEO explained how to customize digital services to customer requirements:

Of course, they're based on different geographies in different technological choices of the customer and so on. With regards to software and so on, there will also always have to be changes based on 
what the customer currently uses and technological choices of the customer. We're trying to do something that fits neatly in anywhere.

\subsection{Ecosystem involvement}

Being part of a well-functioning business ecosystem helps organizations to grow, even in rapidly changing business environments. A business ecosystem consists of a network of interconnected organizations that is constantly evolving and where entities need to be adaptable over time. This research's data analysis showed that SMEs commonly go through ecosystem knowledge synergy, ecosystem integration and ecosystem value co-creation phases, gradually developing their ecosystem involvement and expanding their business boundaries. These issues are discussed next.

4.2.1 Ecosystem knowledge synergy. The members of an ecosystem firstly need to capitalize on "ecosystem knowledge synergy," which is derived from joint knowledge development and collaboration. Based on our analysis, gathering knowledge of global market conditions benefits from ecosystem involvement with, for instance, innovation actors and global trade organizations. If an SME has a plan to export and develop its business internationally by building relationships in the ecosystem, it will be able to use the knowledge of more experienced companies in the international arena. SMEs need to gain a thorough understanding of their target market because this will help them to better understand their audience and generate the right services. They then need to assess their potential partners and their preferences for increasing their international sales. The number of potential partners is huge, and a careful assessment is needed to identify true opportunities for valuable collaboration. The next step is to identify knowledge complementarities with ecosystem partners. SMEs need to get to know their partners well and gain knowledge about how collaboration can deliver joint benefits. Opportunities to find new areas of business development will follow by forming partnerships on an international scale and discovering how to conduct joint development operations beyond domestic boundaries. The CEO of Company $\mathrm{F}$ explained how to identify knowledge complementarities in collaboration with the diverse set of partners in the ecosystem:

We need to learn to talk, we have to sit around, open the door of our sealed rooms a bit and let our partners to know us. And of course, they need to do that too. We need to see where we are standing, where do we want to go together, and how can we help our businesses to reach there and grow in a way that all of us can benefit. It is only by this exchange of knowledge that we can figure out how we can complement each other.

4.2.2 Ecosystem integration. "Ecosystem integration" is one of the most important sources for SMEs to gain resources, improve knowledge, and ultimately boost competitive advantage through partnering. It involves formalizing collaboration with existing and new actors to pursue common goals and create stability for continuous interactions over time. Integration and unity among ecosystem members improve the relationships between its actors. Furthermore, developing routines to coordinate different parts and different actors will strengthen the foundations of that cooperation, especially when working with multiple diverse international partnerships. Effective partnerships are based on recurring and predefined interactions that drive development of the collaboration. Finally, SMEs need to align ecosystem relationships to compete and collaborate simultaneously (coopetition). Dynamic business ecosystems create an environment in which competitors in the ecosystem collaborate even for a limited amount of time. On the issue of coopetition, the CTO of Company C commented:

We are talking about for example Company A, which is both a competitor to us in some cases and also a collaborative partner in some cases. Obviously, it's a more complex situation in the selling phase. 
JOSM

33,1

After going through every step, SMEs will be able to strengthen integration within the ecosystem and learn how to manage interactions in a way that balances all the relationships and entities.

4.2.3 Ecosystem value co-creation. Finally, after a gradual transition from ecosystem knowledge synergy and ecosystem integration, SMEs will be able to enter the highest state of ecosystem involvement - "ecosystem value co-creation." According to our study's findings, this phase includes developing the ability of SMEs to use the value proposition for ecosystem formation. This will be achieved when they convince existing and new ecosystem actors how value that is created jointly will differentiate them from other global competitors. In this way, all will be able to appreciate the benefits of this cooperation and the shaping of their ecosystem for internationalization. Once the foundations are laid, SMEs need to strive to build synergetic and trustful relationships within the ecosystem. Analysis of the collected data reveals that trust has a decisive role in creating new ideas and values in the form of an ecosystem. The sales and marketing manager of Company D recounted how the lack of trust between different stakeholders in an ecosystem can undermine collaboration:

It's trust. If we do not trust each other and you'll start holding information for yourself, I guess that would not be ... that's not a good collaboration. We have to be open, trust and share information to take it forward.

Once trust among different entities and actors of the ecosystem is boosted and institutionalized, SMEs need to develop routines to co-create and expand their joint sphere into the international marketplace. Achieving this trust is certainly not an easy task, particularly internationally, and it is an issue that almost all respondents mentioned in interviews, but all acknowledged that, over time, it can be achieved through lasting and effective collaboration. The data analysis confirmed that maintaining that trust over time is the principal way to catalyze harmony and prompt co-creation between the various components and actors in an ecosystem and to achieve success in internationalizing digital service offerings.

\section{A framework for digital-servitization-enabled internationalization of industrial SMEs}

Based on the empirical results of our study, we see that SMEs, in order to increase their sales in international markets, go through an internationalization process that requires them to develop digital service maturity and to foster ecosystem involvement. Based on our observations of the case company trajectories, we propose a process framework on how industrial SMEs can drive internationalization and global sales growth of their digital service offerings (see Figure 2). Process frameworks have been shown to be valuable in the digital servitization literature because of their path-based approaches (Sjödin et al., 2020a). Our findings reveal that industrial SMEs advance differently in terms of digital service maturity and ecosystem involvement and do not follow the same path in their internationalization process. However, there is no optimal path to SME internationalization. Rather, the selection of a suitable transformation path for international sales growth is dependent upon the SME's ability to drive their digital service maturity forward (i.e. more advanced digital offerings) or to boost the extent of their ecosystem involvement (i.e. forming partnerships to drive international sales).

The framework illustrates how SMEs can take three different paths toward increasing their sales in the international market: (1) a digital servitization innovation strategy, (2) a digital servitization ecosystem strategy and (3) a digital servitization scaling strategy. Because the path and the consequent strategy that an SME chooses depend on its digital service maturity and ecosystem involvement, this framework can be used by SMEs to identify their current 


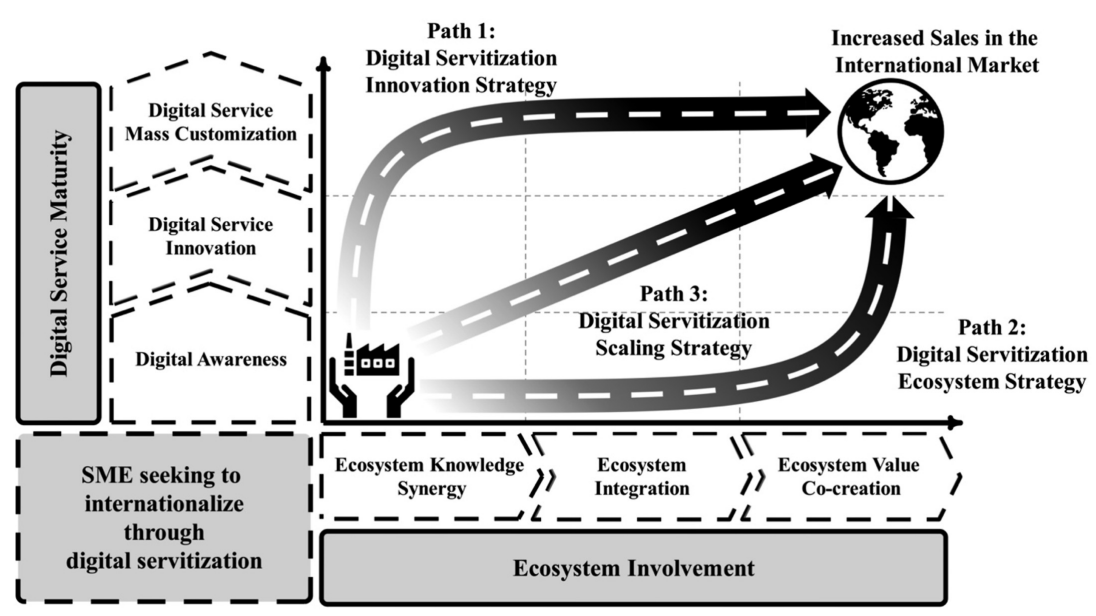

Digital
servitization
strategies

155

Figure 2.

A process framework for digitalservitization-enabled internationalization of industrial SMEs

situation and to determine the path ahead to internationalization. The logic of the different paths is explained below.

The first path is the "digital servitization innovation strategy" where SMEs aim to first strengthen their maturity in digital servitization for the purpose of internationalization [companies $A$ and $B$ followed this path]. The companies that take this path progress through various stages of digital service maturity during their internationalization journey. These companies commonly exhibit high digital awareness, which they deploy to advance digital service innovation of their products. They establish customized digital services principally within existing markets. However, the distinctive feature of this path is that, when SMEs reach high digital service maturity, they use this sophistication to attract partners to increase their ecosystem involvement. This ecosystem involvement can then trigger innovation of their digital service offerings to reach wider global markets or increase the value of their offerings internationally. For example, Company B [a provider of advanced hardware and software solutions to monitor and control the functional safety and reliability of manufacturing in forestry] has provided increasingly sophisticated digital service offerings to Swedish customers. Through increased ecosystem involvement, these offerings are now provided to customers in Japan who were attracted by the advanced services. This has further stimulated increased interest and integration from partners and customers in Asia.

The second path is focused on adopting a "digital servitization ecosystem strategy" to gradually drive digital servitization internationalization [companies D and F followed this path]. In contrast to the first strategy, this strategy prioritizes the involvement of international ecosystem partners, starting with sales of more basic digital services (rather than increasing digital maturity). Many SMEs depend on involvement with ecosystems to internationalize their digital services by accessing the knowledge, skills, and market penetration of international partners. For example, they can distribute their digital services internationally through the distribution networks of other actors. SMEs on this path often utilize support organizations to create ecosystem knowledge synergy by gathering knowledge of international markets, assessing potential partners, and identifying knowledge complementarities with other ecosystem actors. Based on this knowledge, ecosystem integration is reinforced through formalizing collaboration with experienced - and often large - actors to jointly exploit digital technologies in the ecosystem. Finally, at the highest level of ecosystem involvement, SMEs cocreate value with ecosystem partners, which enables the partnership to expand into a larger 
JOSM

33,1

156

international market. Reaching high levels of ecosystem involvement helps SMEs to learn from their partners and accelerate their digital service maturity through collaboration. For example, Company $\mathrm{D}$ [a provider of intelligent measurement systems in 2D and 3D technologies] integrated their system within the products of a large supplier of machinery in the local market. However, that successful collaboration led the companies to formalize their relationship, to further expand the functionalities of the system, and then to offer it on a global scale. The opportunity to reach global markets with the help of the ecosystem partner has now led to independent international sales.

Finally, the third path, which is the fastest and, at the same time, the most resource intensive and difficult path, is related to the "digital servitization scaling strategy" [companies $C$ and $E$ followed this path]. This means that SMEs simultaneously seek to strengthen their digital service maturity and ecosystem involvement. The SME needs to rapidly build the capacity to carry out these two different approaches simultaneously and become somewhat ambidextrous. The goal is to quickly scale digital service offerings and assume international market leadership ahead of the competition, which demands aggressive investment of resources. This is a high-risk/high-reward strategy not suitable for all SMEs. Nevertheless, those SMEs with unique digital service offerings stand to gain from this strategy. Because a high level of digital service maturity and a high level of ecosystem involvement are both required for successful internationalization of industrial SMEs, this strategy recognizes the benefits of simultaneous development rather than the sequential development that the other strategies favor. For example, Company C [a provider of software solutions and digital interfaces for connectivity and optimization of mining sites] has secured global leadership in situational awareness and site optimization services for the mining industry by simultaneously pushing the aggressive development of service innovation and customization and deep ecosystem involvement with a major partner enjoying global reach in its sales and delivery.

\section{Conclusion}

\subsection{Theoretical implications}

This study investigates how digital servitization enables the process of internationalization for industrial SMEs. The findings demonstrate the importance of developing capabilities for digital service offerings and increasingly involving ecosystem partners. More importantly, we identify three distinct internationalization strategies in our process framework. Accordingly, this research provides several theoretical contributions to the digital servitization literature and carries important implications for practitioners, both of which will be discussed next.

First, we contribute by proposing specific insights for the digital servitization transformation of industrial SMEs. SMEs face unique challenges in commercializing digital service offerings, such as liability of smallness and liability of newness (Gimenez-Fernandez et al., 2020). These transformational challenges mean that SMEs cannot replicate the digital servitization implementation of their larger counterparts (Jovanovic et al., 2021). For example, we found that SMEs adopted a restrictive strategy focusing on building either digital service maturity or ecosystem involvement to conserve limited internal resources. While larger firms may have the resources to adopt broader strategies, our findings may still be of interest in that context as a way to cope with digital servitization paradoxes, organizational inertia and a diluted focus (Sjödin et al., 2020b). Additionally, it is harder for a new company to obtain the credit and insurance needed to offer digital services due to their lack of credit history and limited assets. So, newness is connected with legitimacy and whether other companies want to collaborate with new players or not (Landström and Lohrke, 2015). Thus, developing SME-specific insights is of considerable value in developing the digital servitization literature stream. 
Second, we contribute by developing a process framework for SME internationalization strategies. This study recognizes that SMEs are highly heterogeneous in terms of capabilities and strategic orientation. This is aligned with the previous literature, which has shown that the relationship between financial performance and digital servitization depends on many variables (Kohtamäki et al., 2020). Thus, understanding SMEs' strategies for increasing their international sales requires a process framework (Chen et al., 2021; Jovanovic et al., 2021) that considers the gradual phases that an SME must take to achieve its international goals. At its core, our process framework identified two critical dimensions of development that SMEs adopted - namely, digital service maturity and ecosystem involvement. However, our key finding has been the pinpointing of three unique strategies to advance the international development of SMEs: a digital servitization innovation strategy, a digital servitization ecosystem strategy, and a digital servitization scaling strategy. Thus, there are multiple potential strategies for achieving success in the digital-servitization-enabled internationalization of industrial SMEs.

Finally, we contribute by identifying and conceptualizing a fast-tracked digital servitization scaling strategy. The co-evolution of ecosystems and more advanced digital service offerings for digital servitization has been recognized in the literature (Sklyar et al., 2019; Tronvoll et al., 2020; Jovanovic et al., 2021; Sjödin et al., 2021). We argue that SMEs with the ability and capacity to cope with simultaneously developing digital servitization and involvement with ecosystem partners will have the most scaled approach to international growth. The digital servitization scaling strategy is not only a fast, high growth strategy but it also releases additional value that cannot be obtained by approaching digital service maturity and ecosystem involvement sequentially (e.g. first-mover advantages). Thus, the interplay between digital servitization and ecosystem involvement holds unique advantages for the internationalization of digital service offerings.

\subsection{Managerial implications}

In addition to these theoretical contributions, our research has practical implications for SMEs currently engaged in bringing their digital service offerings to the international marketplace and for those intending to do so in the future. Leaders and managers in SMEs can adopt this new perspective to better understand how their firms can survive, adapt, and thrive in a rapidly changing global business environment. In this regard, the managerial/ practical implications of our work can be summarized in two main points. First, SMEs can use the proposed framework to analyze their digital service maturity and ecosystem involvement. They need to identify which phase they are currently in, take steps to consolidate their performance in that phase and then, advance to the next phase. While aiming for higher levels of digital service maturity, SMEs can also learn how to improve their ecosystem involvement for the purpose of internationalization. Indeed, SME leaders need to constantly assess their needs and opportunities in emerging markets to get ready for future disruptions. They can define the maturity and key value propositions of their digital service offerings and the roles they play in the ecosystem. With this framework in mind, they will be able to conceptualize their strategy in promoting global digital service sales, and they will have a better understanding of how different stakeholders influence them, depending on their digital service maturity. Through that learning process, SMEs are likely to improve their internationalization and increase their competitiveness. Second, SMEs are offered guidance emphasizing that there is no one-size-fits-all path to successful internationalization of digital service offerings. For example, for SMEs that rely on strong relationships with their partners in internationalization and digital servitization development, the first step is to strengthen their ecosystem involvement by adopting the proposed phases and sub-activities associated with the digital servitization ecosystem strategy for internationalization. 
JOSM

33,1

158

\subsection{Limitations and future research}

Although the present study makes several novel contributions to the emerging literature on digital servitization, the empirical findings need to be interpreted considering certain limitations that could provide a starting point for future research. The first limitation is related to the limited number of cases studied in this research. It should be highlighted that SMEs are very heterogeneous in terms of their characteristics and performance which can lead to the fact that they might adopt different strategies for increasing their international sales. For example, as found in our analysis, Company B adopted the digital servitization innovation strategy while Company D adopted the digital servitization strategy for internationalization. So, selecting and reviewing a greater number of SMEs or those SMEs operating in other regions or industries may yield different results. The second limitation is related to capturing insights around international markets. Much of our data has been relied on the SMEs internal processes, while their activities and operations in international markets definitely has the potential to be further examined and scrutinized. That could be done along with collecting data and looking into distributers, partnerships, and different strategies that are engaged by them. So, it would be valuable to get deeper insights toward following each strategy and how that interlinks to the ecosystem actors approach. The third limitation relates to the fact that we have identified three different digital servitization strategies which all of them lead toward increasing the SMEs international sales. However, successful internationalization would also be worthy of conducting quantitative studies in order to further dig into the performance outcomes these strategies lead to in terms of increasing sales growth, market share, and entrance to new markets. So, a quantitative study would be helpful for finding the correlations between different strategies and their specific outcomes. Furthermore, this study identifies three paths to the internationalization of digital service offerings. Future studies could explore additional paths or identify criteria and capabilities, such as AI (Sjödin et al., 2021), that favor the adoption of one particular path over another. In addition, further research into the management processes, sub-activities and culture of SMEs adopting the digital servitization scaling strategy would be highly illuminating, helping us to understand how firms successfully cope with rapidly growing their digital service maturity and ecosystem involvement simultaneously.

\section{References}

Adner, R. (2017), "Ecosystem as structure: an actionable construct for strategy", Journal of Management, Vol. 43 No. 1, pp. 39-58.

Adrodegari, F. and Saccani, N. (2020), "A maturity model for the servitization of product-centric companies”, Journal of Manufacturing Technology Management, Emerald Group Publishing, Vol. 31 No. 4, pp. 775-797.

Ayden, Y., Tatoglu, E., Glaister, K.W. and Demirbag, M. (2021), "Exploring the internationalization strategies of Turkish multinationals: a multi-perspective analysis", Journal of International Management, Vol. 27 No. 3, 100783.

Benitez, G.B., Ayala, N.F. and Frank, A.G. (2020), "Industry 4.0 innovation ecosystems: an evolutionary perspective on value cocreation”, International Journal of Production Economics, Elsevier B.V., Vol. 228, p. 107735.

Braun, V. and Clarke, V. (2006), "Using thematic analysis in psychology", Qualitative Research in Psychology, Vol. 3 No. 2, pp. 77-101.

Chen, Y., Visnjic, I., Parida, V. and Zhang, Z. (2021), "On the road to digital servitization - the (dis) continuous interplay between business model and digital technology", International Journal of Operations and Production Management, Emerald Publishing, Vol. 41 No. 5, pp. 694-722. 
Coreynen, W., Matthyssens, P. and Van Bockhaven, W. (2017), "Boosting servitization through digitization: pathways and dynamic resource configurations for manufacturers", Industrial Marketing Management, Elsevier, Vol. 60, pp. 42-53.

Coreynen, W., Matthyssens, P., Vanderstraeten, J. and van Witteloostuijn, A. (2020), "Unravelling the internal and external drivers of digital servitization: a dynamic capabilities and contingency perspective on firm strategy", Industrial Marketing Management, Vol. 89, pp. 265-277.

Cormican, K. (2010), “Collaborative networks: challenges for SMEs”, E-business Managerial Aspects, Solutions and Case Studies, IGI Global, Hershey, pp. 169-184.

Denicolai, S., Zucchella, A. and Magnani, G. (2021), "Internationalization, digitalization, and sustainability: are SMEs ready? A survey on synergies and substituting effects among growth paths”, Technological Forecasting and Social Change, Elsevier, Vol. 166, p. 120650.

Donaldson, L. (2001), "The contingency theory of organizations", available at: https://books.google.com/ books?hl=en\&lr=\&id=hXroN8btsN8C\&oi $=$ fnd\&pg $=$ PR11\&ots $=4$ etgbDQXVw\&sig $=$ etaopd_ wYnFEazghrlzbvCI7-E8 (accessed 3 May 2021).

Eisenhardt, K.M. (1989), "Building theories from case study research", Academy of Management Review, Academy of Management, Vol. 14 No. 4, pp. 532-550.

Eisenhardt, K.M. and Graebner, M.E. (2007a), "Theory building from cases: opportunities and challenges", Academy of Management Journal, Academy of Management, Vol. 50 No. 1, pp. 25-32.

Eisenhardt, K.M. and Graebner, M.E. (2007b), "Theory building from cases: opportunities and challenges", Academy of Management Journal, Academy of Management, Vol. 50 No. 1, pp. 25-32.

Galkina, T. and Chetty, S. (2015), "Effectuation and networking of internationalizing SMEs", Management International Review, Gabler Verlag, Vol. 55 No. 5, pp. 647-676.

Gebauer, H., Paiola, M., Saccani, N. and Rapaccini, M. (2021), "Digital servitization: crossing the perspectives of digitization and servitization", Industrial Marketing Management, Vol. 93, pp. 382-388.

Genc, E., Dayan, M. and Genc, O.F. (2019), "The impact of SME internationalization on innovation: the mediating role of market and entrepreneurial orientation”, Industrial Marketing Management, Elsevier, Vol. 82, pp. 253-264.

Gimenez-Fernandez, E.M., Sandulli, F.D. and Bogers, M. (2020), "Unpacking liabilities of newness and smallness in innovative start-ups: investigating the differences in innovation performance between new and older small firms", Research Policy, North-Holland, Vol. 49 No. 10, p. 104049.

Gioia, D.A., Corley, K.G. and Hamilton, A.L. (2013), "Seeking qualitative rigor in inductive research", Organizational Research Methods, SAGE Publications Sage CA: Los Angeles, CA, Vol. 16 No. 1, pp. $15-31$.

Glaser, B. and Strauss, A. (1967), The Discovery of Grounded Theory: Strategies of Qualitative Research, Wiedenfeld and Nicholson, London.

Håkansson, H. and Snehota, I. (2017), No Business Is an Island: Making Sense of the Interactive Business World, No Business Is an Island, Emerald Publishing, Bingley, doi: 10.1108/ 9781787145498.

Jovanovic, M., Sjödin, D. and Parida, V. (2021), "Co-evolution of platform architecture, platform services, and platform governance: expanding the platform value of industrial digital platforms", Technovation, 102218, (in press).

Kahle, J.H., Marcon, É., Ghezzi, A. and Frank, A.G. (2020), "Smart products value creation in SMEs innovation ecosystems", Technological Forecasting and Social Change, Elsevier, Vol. 156, p. 120024.

Kamalaldin, A., Sjödin, D., Hullova, D. and Parida, V. (2021), "Configuring ecosystem strategies for digitally enabled process innovation: a framework for equipment suppliers in the process industries", Technovation, Vol. 105, doi: 10.1016/j.technovation.2021.102250. 
JOSM

33,1

Kohtamäki, M., Parida, V., Oghazi, P., Gebauer, H. and Baines, T. (2019), "Digital servitization business models in ecosystems: a theory of the firm", Journal of Business Research, Elsevier, Vol. 104, pp. 380-392.

Kohtamäki, M., Parida, V., Patel, P.C. and Gebauer, H. (2020), "The relationship between digitalization and servitization: the role of servitization in capturing the financial potential of digitalization", Technological Forecasting and Social Change, Elsevier, Vol. 151, p. 119804.

Kowalkowski, C., Witell, L. and Gustafsson, A. (2013), "Any way goes: identifying value constellations for service infusion in SMEs", Industrial Marketing Management, Vol. 42 No. 1, pp. 18-30.

Kowalkowski, C., Gebauer, H., Kamp, B. and Parry, G. (2017), "Servitization and deservitization: overview, concepts, and definitions", Industrial Marketing Management, Vol. 60, pp. 4-10.

Kraus, S., Mitter, C., Eggers, F. and Stieg, P. (2016), "Drivers of internationalization success: a conjoint choice experiment on German SME managers", Review of Managerial Science 2016, 11:3, Springer, Vol. 11 No. 3, pp. 691-716.

Landström, H. and Lohrke, F. (2015), New Advantage and Liability Sources in Entrepreneurial Firms: Assessing Progress and Exploring Possibilities, Vol. 40, No. 1, SAGE Publications Sage CA, Los Angeles, CA, pp. 121-124, doi: 10.1177/1059601114568240.

Lincoln, Y. and Guba, E. (1985), Naturalistic Enquiry, Sage, Beverley Hills, CA.

Linde, L., Sjödin, D., Parida, V. and Wincent, J. (2021), "Dynamic capabilities for ecosystem orchestration a capability-based framework for smart city innovation initiatives", Technological Forecasting and Social Change, Vol. 166, doi: 10.1016/j.techfore.2021.120614.

Martín-Peña, M.L., Sánchez-López, J.M. and Díaz-Garrido, E. (2020), "Servitization and digitalization in manufacturing: the influence on firm performance", Journal of Business and Industrial Marketing, Vol. 35 No. 3, pp. 564-574, doi: 10.1108/JBIM-12-2018-0400.

Matlay, H., Ruzzier, M., Hisrich, R.D. and Antoncic, B. (2006), "SME internationalization research: past, present, and future", Journal of Small Business and Enterprise Development, Emerald Group Publishing, Vol. 13 No. 4, pp. 476-497.

Naik, P., Schroeder, A., Kapoor, K.K., Ziaee Bigdeli, A. and Baines, T. (2020), "Behind the scenes of digital servitization: actualising IoT-enabled affordances", Industrial Marketing Management, Vol. 89, pp. 232-244.

Niittymies, A. and Pajunen, K. (2020), "Cognitive foundations of firm internationalization: a systematic review and agenda for future research", International Business Review, Vol. 29 No. 4, 101654.

Paschou, T., Rapaccini, M., Adrodegari, F. and Saccani, N. (2020), "Digital servitization in manufacturing: a systematic literature review and research agenda", Industrial Marketing Management, Vol. 89, pp. 278-292.

Peillon, S. and Dubruc, N. (2019), "Barriers to digital servitization in French manufacturing SMEs", Procedia CIRP, Elsevier B.V., Vol. 83, pp. 146-150.

Pergelova, A., Manolova, T., Simeonova-Ganeva, R. and Yordanova, D. (2019), "Democratizing entrepreneurship? Digital technologies and the internationalization of female-led SMEs", Journal of Small Business Management, Blackwell Publishing, Vol. 57 No. 1, pp. 14-39.

Queiroz, S.A.B., Mendes, G.H.S., Silva, J.H.O., Ganga, G.M.D., Cauchick, Miguel, P.A. and Oliveira, M.G. (2020), "Servitization and performance: impacts on small and medium enterprises", Journal of Business and Industrial Marketing, Vol. 35 No. 7, pp. 1237-1249, doi: 10.1108/JBIM06-2019-0277.

Raddats, C., Kowalkowski, C., Benedettini, O., Burton, J. and Gebauer, H. (2019), "Servitization: a contemporary thematic review of four major research streams", Industrial Marketing Management, Elsevier, Vol. 83, pp. 207-223.

Radziwon, A. and Bogers, M. (2019), "Open innovation in SMEs: exploring inter-organizational relationships in an ecosystem”, Technological Forecasting and Social Change, Elsevier, Vol. 146, pp. 573-587. 
Reim, W., Sjödin, D.R. and Parida, V. (2019), "Servitization of global service network actors - a contingency framework for matching challenges and strategies in service transition", Journal of Business Research, Vol. 104, pp. 461-471.

Reim, W., Sjödin, D. and Parida, V. (2021), "Circular business model implementation: a capability development case study from the manufacturing industry", Business Strategy and the Environment, Vol. 30 No. 6, pp. 2745-2757.

Roy, A., Sekhar, C. and Vyas, V. (2016), "Barriers to internationalization: a study of small and medium enterprises in India", Journal of International Entrepreneurship, Springer New York LLC, Vol. 14 No. 4, pp. 513-538.

Schroeder, A., Naik, P., Ziaee Bigdeli and Baines, T. (2020), "Digitally enabled advanced services: a socio-technical perspective on the role of the Internet of Things (IoT)", International Journal of Operations and Production Management, Vol. 40 Nos 7/8, pp. 1243-1268, doi: 10.1108/IJOPM-032020-0131.

Senik, Z.C., Scott-Ladd, B., Entrekin, L. and Adham, K.A. (2011), "Networking and internationalization of SMEs in emerging economies", Journal of International Entrepreneurship, Springer, Vol. 9 No. 4, pp. 259-281.

Sinkovics, N., Sinkovics, R.R. and Jean, R.J.B. (2013), "The internet as an alternative path to internationalization?”, International Marketing Review, Emerald Group Publishing, Vol. 30 No. 2, pp. 130-155.

Sjödin, D., Parida, V., Jovanovic, M. and Visnjic, I. (2020a), "Value creation and value capture alignment in business model innovation: a process view on outcome-based business models", Journal of Product Innovation Management, John Wiley \& Sons, Vol. 37 No. 2, pp. 158-183.

Sjödin, D., Parida, V., Kohtamäki, M. and Wincent, J. (2020b), “An agile co-creation process for digital servitization: a micro-service innovation approach”, Journal of Business Research, Elsevier, Vol. 112, pp. 478-491.

Sjödin, D., Parida, V., Palmie, M. and Wincent, J. (2021), "How AI capabilities enable business model innovation: scaling AI through co-evolutionary processes and feedback loops", Journal of Business Research, Vol. 134, pp. 574-587, doi: 10.1016/j.jbusres.2021.05.009.

Sklyar, A., Kowalkowski, C., Tronvoll, B. and Sörhammar, D. (2019), "Organizing for digital servitization: a service ecosystem perspective”, Journal of Business Research, Elsevier, Vol. 104, pp. $450-460$.

Su, F., Khan, Z., Kyu Lew, Y., Il Park, B. and Shafi Choksy, U. (2020), "Internationalization of Chinese SMEs: the role of networks and global value chains", BRQ Business Research Quarterly, SAGE Publications, Vol. 23 No. 2, pp. 141-158.

Thompson, J. (2003), Organizations in Action: Social Science Bases of Administrative Theory.

Tronvoll, B., Sklyar, A., Sörhammar, D. and Kowalkowski, C. (2020), "Transformational shifts through digital servitization”, Industrial Marketing Management, Elsevier, Vol. 89, pp. 293-305.

Vahlne, J.E. (2020), "Development of the Uppsala model of internationalization process: from internationalization to evolution", Global Strategy Journal, Wiley-Blackwell Publishing, Vol. 10 No. 2, pp. 239-250.

Valtakoski, A. and Witell, L. (2018), Service Capabilities and Servitized SME Performance: Contingency on Firm Age, doi: 10.1108/IJOPM-06-2016-0328.

Weerawardena, J., Salunke, S., Knight, G., Mort, G.S. and Liesch, P.W. (2020), “The learning subsystem interplay in service innovation in born global service firm internationalization", Industrial Marketing Management, Elsevier, Vol. 89, pp. 181-195.

Yin, R.K. (2014), Case Study Research: Design and Methods (Applied Social Research Methods), SAGE Publications, Thousand Oaks, CA.

Yin, R. (2017), Case Study Research and Applications: Design and Methods, SAGE Publications, Thousand Oaks. 
JOSM

33,1

Ziaee Bigdeli, A., Baines, T., Bustinza, O.F. and Guang Shi, V. (2017), "Organisational change towards servitization: a theoretical framework”, Competitiveness Review, Vol. 27 No. 1, pp. 12-39, doi: 10. 1108/CR-03-2015-0015.

Ziaee Bigdeli, A., Baines, T., Schroeder, A., Brown, S., Musson, E., Guang Shi, V. and Calabrese, A. (2018), "Measuring servitization progress and outcome: the case of 'advanced services", Production Planning and Control, Vol. 29 No. 4, pp. 315-332.

\section{2}

\section{Corresponding author}

Wiebke Reim can be contacted at: wiebke.reim@ltu.se

For instructions on how to order reprints of this article, please visit our website: www.emeraldgrouppublishing.com/licensing/reprints.htm Or contact us for further details: permissions@emeraldinsight.com 